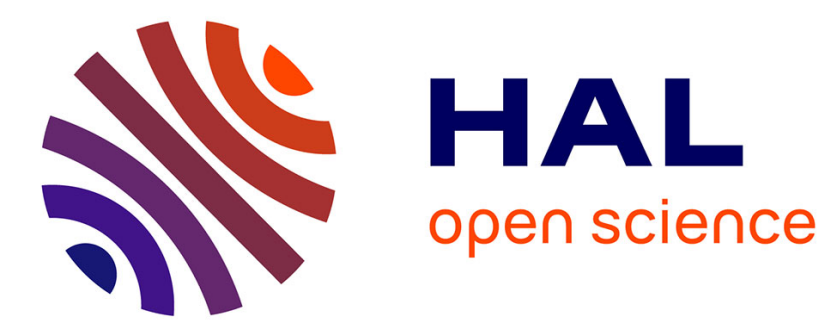

\title{
Reduced sensitivity to paraquat evolves under selection with low glyphosate doses in Lolium rigidum
}

Busi, Stephen Powles

\section{To cite this version:}

Busi, Stephen Powles. Reduced sensitivity to paraquat evolves under selection with low glyphosate doses in Lolium rigidum. Agronomy for Sustainable Development, 2011, 31 (3), pp.525-531. 10.1007/s13593-011-0012-6 . hal-00930479

\section{HAL Id: hal-00930479 \\ https://hal.science/hal-00930479}

Submitted on 1 Jan 2011

HAL is a multi-disciplinary open access archive for the deposit and dissemination of scientific research documents, whether they are published or not. The documents may come from teaching and research institutions in France or abroad, or from public or private research centers.
L'archive ouverte pluridisciplinaire HAL, est destinée au dépôt et à la diffusion de documents scientifiques de niveau recherche, publiés ou non, émanant des établissements d'enseignement et de recherche français ou étrangers, des laboratoires publics ou privés. 


\title{
Reduced sensitivity to paraquat evolves under selection with low glyphosate doses in Lolium rigidum
}

\author{
Roberto Busi • Stephen B. Powles
}

Accepted: 4 January 2011 / Published online: 15 February 2011

(C) INRA and Springer Science+Business Media B.V. 2011

\begin{abstract}
This is the first report of low-dose glyphosate selection causing a shift towards paraquat resistance. Herbicide resistance in weed species is a serious threat to world agriculture. We report rapid resistance evolution in the genetically variable cross-pollinated grass weed Lolium rigidum when recurrently selected with low doses. Results show that an herbicide-susceptible $L$. rigidum population selected over three generations with below-label doses of glyphosate exhibited not only glyphosate resistance evolution but also a progressive and concomitant shift in sensitivity to the structurally unrelated herbicide paraquat. Thus, reduced paraquat sensitivity was a consequence of recurrent selection with glyphosate at low doses. In the three-time glyphosate-selected progeny, the estimated paraquat dose to cause $50 \%$ mortality $\left(\mathrm{LD}_{50}\right)$ was 4 -fold greater than for the unselected susceptible parent. Studying the evolutionary outcomes of below-label herbicide dose selection can help prevent genetic changes in weed populations and sustain the efficacy of herbicides widely used in world agriculture.
\end{abstract}

Keywords Glyphosate $\cdot$ Paraquat $\cdot$ Rigid ryegrass $\cdot$ Lolium rigidum Gaud. Herbicide resistance · Herbicide sensitivity Recurrent selection $\cdot$ Rapid resistance evolution

R. Busi $(\bowtie) \cdot$ S. B. Powles

Australian Herbicide Resistance Initiative,

School of Plant Biology, UWA Institute of Agriculture,

The University of Western Australia,

35 Stirling Hwy, Crawley,

Perth, WA 6009, Australia

e-mail: roberto.busi@uwa.edu.au

\section{Introduction}

In modern agro-systems crop productivity losses due to pests are significant and crop protection with pesticides remains essential (Oerke 2006). Despite their success, the persistent use of fungicides, insecticides, herbicides, as well as antimicrobials has often resulted in resistance evolution in pathogens, pest insects, and weeds (Palumbi 2001).

For more than 35 years, the very dissimilar herbicides glyphosate and paraquat have been used globally. Both herbicides provide non-selective, broad-spectrum weed control and can often be used interchangeably. Glyphosate inhibits the activity of 5-enolpyruvyl-shikimate-3-phosphate synthase (EPSPS, EC 2.5.1.19) in the shikimate pathway in plants, thus preventing the synthesis of aromatic amino acids and secondary metabolites (Shaner 2009). Paraquat targets photosystem I in the chloroplast and induces production of superoxide radicals, causing membrane damage, leaf desiccation, and subsequent rapid plant death (Preston 1994). In the last few years, reliance on glyphosate as a principal tool for weed control in transgenic glyphosate-resistant crops has resulted in the evolution of several glyphosate-resistant weed species and changes in weed flora composition (Owen 2008; Powles 2008). Similarly, several weed species have evolved paraquat resistance, although it is confined to small areas (Preston 1994; Heap 2010). Glyphosate resistance can be endowed by individual plants possessing one or more of at least four different glyphosate resistance mechanisms (reviewed by Shaner 2009; Powles and Yu 2010). Studies on evolved non-target-site glyphosate- or paraquat-resistant weed species such as Conyza spp., Lolium spp., and Hordeum spp. have established that single major genes are responsible for conferring resistance (Purba et al. 1993; Lorraine-Colwill et al. 2001; Zelaya et al. 2004; Yu et al. 2009). However, inheritance studies with glyphosate- or 
paraquat-resistant biotypes of Lolium rigidum Gaud. suggest that other minor genes may have contributed to the observed higher-than-expected plant survival at low herbicide doses in back-crosses or F2 families (Lorraine-Colwill et al. 2001; Yu et al. 2009). In L. rigidum, non-target-site resistance to glyphosate or paraquat can be endowed by independent mechanisms manifest as reduced glyphosate or paraquat translocation (Yu et al. 2007). However, for both herbicides, the precise biochemical and molecular basis of non-target-site resistance mechanism(s) remains unclear (Shaaltiel and Gressel 1986; Preston 1994; Yasuor et al. 2008; Shaner 2009).

A glyphosate-susceptible L. rigidum population evolved moderate glyphosate resistance when selected with belowlabel glyphosate doses for three consecutive generations (Busi and Powles 2009). Here, we report that reduced paraquat sensitivity concomitantly evolved in the same glyphosate-selected progeny.

\section{Materials and methods}

\subsection{Plant material}

A L. rigidum parent population (biotype VLR1), susceptible to all herbicides registered for L. rigidum control, was selected with low glyphosate doses over three to four consecutive generations in two distinct environments (controlled vs. outdoors), resulting in moderate glyphosate resistance evolution (Busi and Powles 2009). These populations were used in this study. They were numbered according to their generation and designated "a" if selected under controlled conditions, and "b", "c", or "d" if selected outdoors simulating field

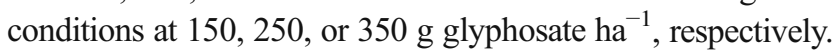

\subsection{Herbicide sensitivity profiling}

of the glyphosate-selected population under controlled conditions

We investigated if recurrent selection of the herbicidesusceptible parent (VLR1) with low doses of glyphosate altered sensitivity to herbicides of unrelated herbicide chemistries, when plants were grown, selected, and treated in a controlled environment room at $20 / 12^{\circ} \mathrm{C}$ under fluorescent light $\left(300 \mu \mathrm{mol}\right.$ quanta $\left.\mathrm{m}^{-2} \mathrm{~s}^{-1}\right)$ with a photoperiod of $16 \mathrm{~h}$ (light phase coinciding with the warm phase). Growing conditions, populations, and glyphosate selection were described (Busi and Powles 2009). The four-time glyphosate-selected population (progeny 4a; Table 1) and the unselected susceptible parent population (VLR1) were analyzed by herbicide dose-response studies. Plants at twoleaf stage were treated with $0,150,300,600,1,200$, and 2,400 $\mathrm{g}$ atrazine ha ${ }^{-1}$ (label rate 2,400 $\mathrm{g} \mathrm{ha}^{-1}$ ); 0, 7.5, 15, and $30 \mathrm{~g}$ chlorsulfuron ha ${ }^{-1}$ (label rate $20 \mathrm{~g} \mathrm{ha}^{-1}$ ); 0, 47, 94, 188, and $375 \mathrm{~g}$ diclofop-methyl ha ${ }^{-1}$ (label rate $375 \mathrm{~g} \mathrm{ha}^{-1}$ ); and
$0,6,13,25$, and $50 \mathrm{~g}_{\text {paraquat }} \mathrm{ha}^{-1}$ (label rate $200 \mathrm{~g} \mathrm{ha}^{-1}$ ). Plant survival and aboveground fresh biomass were assessed 15 days after herbicide application. Survivors were identified as plants able to grow vigorously after biomass assessment. For each herbicide dose, there were three replicates (15 plants per pot) in a completely randomized design. The pot represented the experimental unit and plant weights of all 15 plants pooled. The paraquat dose-response study was repeated in time (Table 1). Dose-response data from repeated experiments were analyzed by a lack-of-fit $F$ test and found significantly different $(P<0.05)$. Thus, data sets were kept separate in subsequent non-linear regression analysis.

Neve and Powles (2005) subjected the same herbicide susceptible VLR1 population to recurrent low-dose diclofopmethyl selection and reported high-level diclofop-methyl resistance evolution (progeny VLR1 0105 10). These plants were evaluated at a range of glyphosate $(0,75,150,250,350$, and $450 \mathrm{~g}$ glyphosate $\mathrm{ha}^{-1}$; label rate $450 \mathrm{~g} \mathrm{ha}^{-1}$ ) or paraquat doses $\left(0,6,13,25\right.$, and $\left.50 \mathrm{~g}_{\text {paraquat }} \mathrm{ha}^{-1}\right)$ to assess whether unspecific low-dose herbicide selection per se with another herbicide mode of action was decreasing the sensitivity to glyphosate and paraquat as observed in progeny $4 \mathrm{a}$.

\subsection{Paraquat sensitivity of the glyphosate-selected} populations grown outdoors

Experiments were conducted during the normal southern Australian winter growing season (May-August), with plants grown outdoors to closely simulate field conditions (Busi and Powles 2009). The mean photoperiod was $11 \mathrm{~h}$ with $700 \mu \mathrm{mol}$ quanta $\mathrm{m}^{-2} \mathrm{~s}^{-1}$ (daily mean) and mean temperatures were 21/ $16^{\circ} \mathrm{C}$ (day/night). The herbicide susceptible parent population VLR1 was subjected to low-dose glyphosate selection and surviving plants were recurrently selected for three consecutive generations (Busi and Powles 2009). In 2008, bioassays were conducted on field-selected plants to investigate whether recurrent selection at low doses of glyphosate in field conditions had altered their paraquat sensitivity (Table 1). Two-leaf stage seedlings were treated with $0,6,13,25$, or $50 \mathrm{~g}$ paraquat $\mathrm{ha}^{-1}$, and survival and aboveground fresh biomass were assessed 15 days after herbicide treatment. For each herbicide dose, there were three replicates (15 plants per pot) in a completely randomized design. The pot represented the experimental unit and plant weights of all 15 plants pooled. The experiment was repeated in time. Data from repeated experiments were pooled for subsequent non-linear regression analysis following a lack-of-fit $F$ test $(P>0.05)$.

\subsection{Statistics applied to dose-response studies}

Plant survival and relative biomass data were transformed and expressed as percentages as described by Knezevic et al. (2007). Data sets from repeated experiments were fitted 
Table $1 \mathrm{LD}_{50}$ and $\mathrm{GR}_{50}$ values of four-time glyphosate-selected (progeny $4 \mathrm{a}$ ) and unselected plants (VLR1) and their R/S ratios from paraquat dose-response studies under controlled conditions

\begin{tabular}{lcccccccc}
\hline Generation $^{\mathrm{a}}$ & Exp. & Temperature, ${ }^{\circ} \mathrm{C}$ & $\mathrm{LD}_{50}{ }^{\mathrm{d}}, \mathrm{g} \mathrm{ha}^{-1}$ & $\mathrm{R} / \mathrm{S}^{\mathrm{e}}$ & $P$ value $^{\mathrm{b}}$ & $\mathrm{GR}_{50}{ }^{\mathrm{c}}, \mathrm{g} \mathrm{ha}^{-1}$ & $\mathrm{R}^{-\mathrm{S}}$ & $P$ value $^{\mathrm{b}}$ \\
\hline VLR1 & 1 & $20 / 12$ & $9.6(0.9)$ & 1.0 & & $3.8(1.2)$ & 1.0 \\
4a & 1 & & $20.2(1.8)$ & 2.11 & $<0.001$ & $7.4(1.4)$ & 1.93 & $<0.001$ \\
VLR1 & 2 & $25 / 15$ & $25.5(2.1)$ & 1.0 & & $11.6(1.0)$ & 1.0 & 1.0 \\
4a & 2 & & $38.8(2.9)$ & 1.52 & $<0.001$ & $15.1(2.5)$ & 1.30 & $<0.001$ \\
\hline
\end{tabular}

Standard errors of estimated $\mathrm{LD}_{50}$ or $\mathrm{GR}_{50}$ values are given in parentheses. ANOVA analysis conducted for each non-linear regression model $Y=c+\left[(d-c) /\left[1+(x / G)^{b}\right]\right.$ was highly significant $(P<0.001)$ with adjusted $R^{2}>0.91$

${ }^{a}$ Progeny 4 a recurrently selected for four generations in a controlled environment at a range of low glyphosate doses (see also Busi and Powles 2009)

${ }^{\mathrm{b}}$ Lack-of-fit $F$ test for statistical difference between the selected progeny $4 \mathrm{a}$ and unselected parent VLR1

${ }^{\mathrm{c}}$ Fresh aboveground biomass

${ }^{\mathrm{d}}$ Herbicide doses causing $50 \%$ plant mortality

${ }^{\mathrm{e}}$ Resistant/susceptible ratio

to a non-linear logistic model with SigmaPlot 2001 version 7.0 and analyzed by ANOVA $F$ test to assess whether the independent variable could be used to predict the dependent variable and the non-linear model provided acceptable description of the data for $P<0.05$. Regression assumptions were held under square root data transformation (i.e., BoxCox transformation lambda $\lambda=0.5)$. The herbicide doses causing $50 \%$ plant mortality $\left(\mathrm{LD}_{50}\right)$ or growth reduction as fresh aboveground biomass $\left(\mathrm{GR}_{50}\right)$ in the selected and unselected populations at each generation were estimated by using the non-linear logistic model:

$Y=c+\left[(d-c) /\left[1+(x / G)^{b}\right]\right.$

$Y$ denotes the plant survival or fresh biomass expressed as a percentage of the untreated control; $d$ and $c$ are upper and lower asymptotic values of $Y$, respectively; $b$ is the slope of the curve; $G$ is the herbicide dose at the point of inflection halfway between the upper and the lower asymptotes, and $x$ is the herbicide dose. The response to selection and the subsequent shift in herbicide sensitivity for the different selected progenies was measured as the R/S (resistant/ susceptible) ratio of estimated $\mathrm{LD}_{50}$ or $\mathrm{GR}_{50}$ values. Statistical differences between unselected parent and selected progenies were assessed by a lack-of-fit $F$ test applied to data sets fitted with the above non-linear logistic model.

\section{Results and discussion}

3.1 Herbicide sensitivity profile in controlled environment-grown plants

The glyphosate-resistant plants resulting from four cycles of glyphosate selection at low doses (progeny 4a), and the

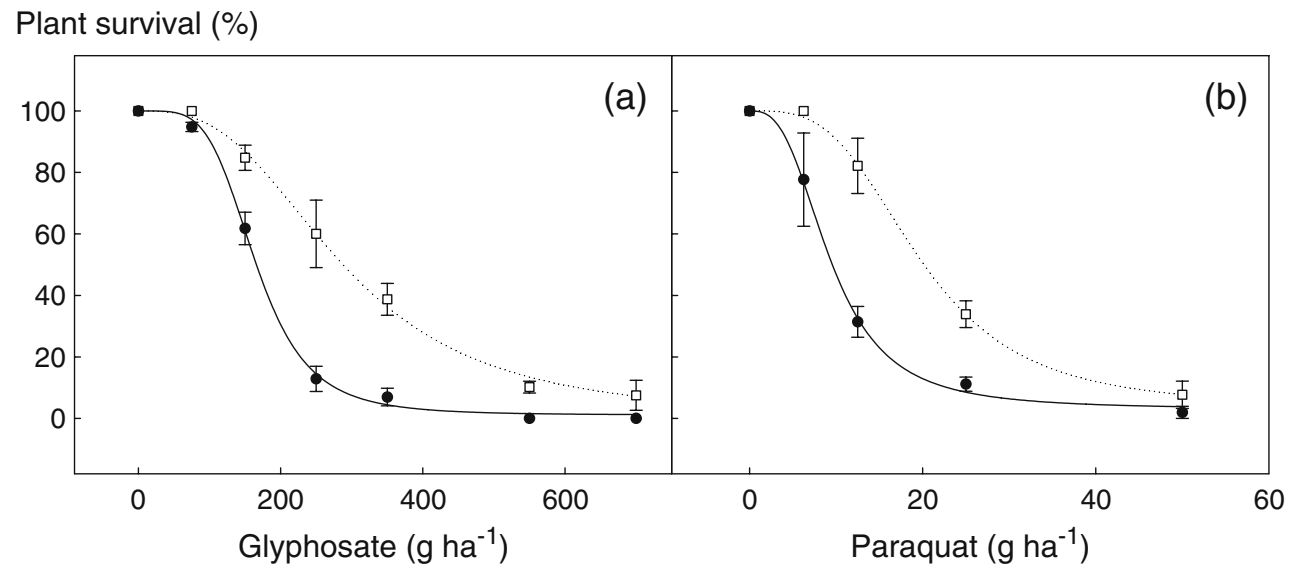

Fig. 1 Plant survival dose-response curves at a range of glyphosate (a) and paraquat (b) doses for the glyphosate-selected progeny $4 \mathrm{a}$. Both selection and evaluation occurred with plants grown in a controlled environment room. Solid circles and solid line represent the unselected parent population (VLR1); open squares and dotted line, the selected the progeny $4 \mathrm{a}$. Symbols are mean $\pm 1 \mathrm{SE}, n=3$, lines are predicted values for percentage survival. The non-linear logistic model $Y=c+\left[(d-c) /\left[1+(x / G)^{b}\right]\right.$ was fitted to data. [Fig. 1a from Busi and Powles 2009; Fig. 1b refers to Table 1 (exp. 1)] 
Fig. 2 Plant survival at a range of glyphosate (a) and paraquat (b) doses for the progeny VLR1 010210 selected three times under controlled environmental conditions (Neve and Powles 2005; open circles, dashed line) and unselected parent population VLR1 (solid circles, solid line). Symbols are mean $\pm 1 \mathrm{SE}$, $n=3$, lines are predicted values for percentage survival. The non-linear logistic model $Y=$ $c+\left[(d-c) /\left[1+(x / G)^{b}\right]\right.$ was fitted to data
Plant survival (\%)

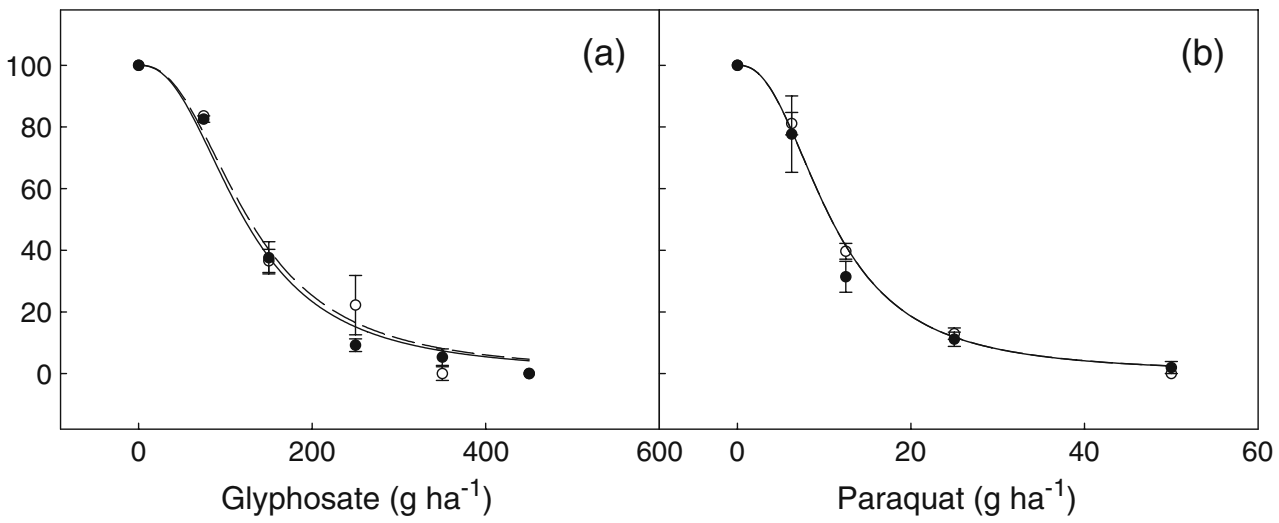

susceptible parent VLR1 population were evaluated across a range of glyphosate or paraquat doses. Along with the shift to glyphosate resistance, a concomitant, clear and significant shift to reduced paraquat sensitivity was evident (by assessing both plant survival and biomass in two different experiments) in progeny 4a (Fig. 1; Table 1). Temperature is a major factor affecting the plant response to paraquat (Preston et al. 2005; Purba et al. 1995; Yu et al. 2004). Similarly here, we observed higher paraquat efficacy and greater differential sensitivity to paraquat between the unselected parental and glyphosate-selected plants grown at lower temperature (Table 1).

The observed change in paraquat sensitivity is the result of low-dose glyphosate selection and is not caused by low-dose herbicide selection per se. The response of the same parental VLR1 population and the progeny subjected to three cycles of recurrent selection at low doses of diclofop-methyl (progeny VLR1 0105 10; Neve and Powles 2005) was evaluated with a range of both paraquat and glyphosate doses. This progeny (VLR1 0105 10) is resistant to diclofop-methyl, but remained equally and fully susceptible to paraquat or glyphosate $(P>0.162$; Fig. 2$)$. The responses of four-time glyphosate-selected progeny $4 \mathrm{a}$ and the unselected parent VLR1 showed no difference in sensitivity to a range of doses of three other herbicides with different modes of action (atrazine, chlorsulfuron, and diclofop-methyl; data not shown), thus establishing that it was only paraquat sensitivity that was associated with glyphosate resistance

\subsection{Paraquat reduced sensitivity of outdoor field-grown plants}

Dose-response studies with the one-, two-, and three-time glyphosate-selected progenies, produced from the suscepti-

Table $2 \mathrm{LD}_{50}$ and $\mathrm{GR}_{50}$ values of selected progenies and unselected plants (VLR1) and their R/S ratios from paraquat dose-response studies outdoors simulating field conditions

\begin{tabular}{|c|c|c|c|c|c|c|}
\hline Generation $^{\mathrm{a}}$ & $\mathrm{LD}_{50}{ }^{\mathrm{d}}, \mathrm{g} \mathrm{ha}^{-1}$ & $\mathrm{R} / \mathrm{S} * *$ & $P$ value $^{\mathrm{b}}$ & $\mathrm{GR}_{50}{ }^{\mathrm{c}}, \mathrm{g} \mathrm{ha}^{-1}$ & $\mathrm{R} / \mathrm{S}^{\mathrm{e}}$ & $P$ value $^{\mathrm{b}}$ \\
\hline VLR1 & $11.4(0.6)$ & 1.0 & & $6.68(0.7)$ & 1.0 & \\
\hline $1 \mathrm{~b}$ & $11.7(1.3)$ & 1.03 & 0.508 & $8.78(0.6)$ & 1.31 & 0.177 \\
\hline $3 b$ & $13.8(0.8)$ & 1.21 & 0.090 & $7.90(0.5)$ & 1.18 & 0.244 \\
\hline $1 \mathrm{c}$ & $14.3(0.8)$ & 1.25 & 0.096 & $7.88(1.0)$ & 1.18 & 0.063 \\
\hline $2 \mathrm{c}$ & $19.3(5.1)$ & 1.69 & $<0.001$ & $11.0(1.0)$ & 1.65 & $<0.001$ \\
\hline $3 \mathrm{c}$ & $37.4(24)$ & 3.28 & $<0.001$ & $13.7(6.8)$ & 2.05 & $<0.001$ \\
\hline $1 d$ & $29.0(12)$ & 2.55 & $<0.001$ & $12.4(4.4)$ & 1.86 & $<0.001$ \\
\hline $2 d$ & $26.4(8.4)$ & 2.32 & $<0.001$ & $12.3(3.8)$ & 1.84 & $<0.001$ \\
\hline $3 d$ & $44(28)$ & 3.86 & $<0.001$ & $18.1(18)$ & 2.72 & $<0.001$ \\
\hline
\end{tabular}

Standard errors of estimated $\mathrm{LD}_{50}$ or $\mathrm{GR}_{50}$ values are given in parentheses. ANOVA analysis conducted for each non-linear regression model $Y=c+\left[(d-c) /\left[1+(x / G)^{b}\right]\right.$ was highly significant $(P<0.001)$ with adjusted $R^{2}>0.85$

${ }^{a}$ Generations numbered according to their generation and designated "b", "c", or "d" if recurrently selected outdoors at 150, 250 , or $350 \mathrm{~g}$ glyphosate ha ${ }^{-1}$, respectively (see also Busi and Powles 2009). Generation $2 \mathrm{~b}$ was not tested in the final dose-response study for insufficient seed production

${ }^{\mathrm{b}}$ Lack-of-fit $F$ test for statistical difference between the each selected progeny "b", "c", and "d" and unselected parent VLR1

${ }^{\mathrm{c}}$ Fresh aboveground biomass

${ }^{\mathrm{d}}$ Herbicide doses causing $50 \%$ plant mortality

${ }^{\mathrm{e}}$ Resistant/susceptible ratio 
ble parent VLR1 population in simulated field conditions, demonstrated the same glyphosate resistance evolution and concomitant shift in paraquat sensitivity as evident in the controlled environment grown progeny $4 \mathrm{a}$ (Table 2). At each of the three generations of recurrent glyphosate selection, the shift in glyphosate resistance was mirrored by a concomitant shift towards reduced paraquat sensitivity (Fig. 3; Table 2). Plant survival at a low paraquat dose $\left(25 \mathrm{~g} \mathrm{ha}^{-1}\right.$ ) was $2.5 \%$ in the unselected parent population VLR1 but increased to $76 \%$ survival in the three-time glyphosate-selected progeny 3d (Fig. 3f). It is emphasized that the unselected susceptible parent population VLR1 was included in each experiment to indicate the environmental variability that is known to influence paraquat doseresponse studies and compare the phenotypic responses of the glyphosate-selected progenies. The greatest shift in reduced paraquat sensitivity was evident in progeny from the most intense glyphosate selections, progeny $3 \mathrm{c}$ and $3 \mathrm{~d}$ (Table 2). Similarly, the maximum glyphosate resistance levels were observed in the progenies selected at the highest glyphosate doses (250 and $350 \mathrm{~g} \mathrm{ha}^{-1}$ ), respectively (Busi and Powles 2009). In a separate outdoor experiment, we also observed a very low frequency of plants (1\%) from the original population VLR1 surviving paraquat at the recommended field dose $\left(200 \mathrm{~g} \mathrm{ha}^{-1}\right)$, whereas the glyphosate-selected progeny $3 \mathrm{c}$ and $3 \mathrm{~d}$ displayed up to $15 \%$ plant survival (data not shown). By contrast, the populations recurrently selected at $150 \mathrm{~g}$ glyphosate ha ${ }^{-1}$ $(1 \mathrm{~b}, 3 \mathrm{~b})$ did not display significantly reduced paraquat sensitivity $(P>0.090$; Fig. 3; Table 2$)$. Consistently, there was good correlation between survival and biomass (Table 2).

A substantial population shift was evident by comparing the unselected parent VLR1 to the outdoor-selected progenies with a three-fold decrease in paraquat sensitivity, expressed as the R/S ratio of $\mathrm{LD}_{50}$ and $\mathrm{GR}_{50}$ values by the third generation (Table 2). By analysis of plant survival dose-response curves and $\mathrm{R} / \mathrm{S}$ ratios, it is clear that the
Fig. 3 Recurrent selection with sub-lethal glyphosate doses in field conditions resulted in reduced sensitivity to paraquat. Plant survival dose-response curves to a range of glyphosate $(\mathbf{a}-\mathbf{c})$ and paraquat $(\mathbf{d}-\mathbf{e})$ doses of glyphosate-selected progenies in field conditions at $150(\mathbf{a}, \mathbf{d})$, $250(\mathbf{b}, \mathbf{e})$, or $350(\mathbf{c}, \mathbf{f}) \mathrm{g}$ glyphosate $\mathrm{ha}^{-1}$. Solid lines and circles represent the unselected parent population (VLR1). Open circles and dashed lines are the once glyphosate-selected progeny at 150,250 , or $350 \mathrm{~g}$ glyphosate ha ${ }^{-1}$ (progeny $1 \mathrm{~b}$, $1 \mathrm{c}, 1 \mathrm{~d})$; open triangles and dash-dotted lines the twice glyphosate-selected progeny (progeny 2c, 2d); open squares and dotted lines the three-time glyphosate-selected progenies (progeny 3b, 3c, 3d). Symbols are mean $\pm 1 \mathrm{SE}, n=6$, lines are predicted values for percentage survival. The non-linear logistic model $Y=c+$

$\left[(d-c) /\left[1+(x / G)^{b}\right]\right.$ was fitted to data. Figure $3 \mathrm{a}, \mathrm{b}, \mathrm{c}$ from Busi and Powles 2009

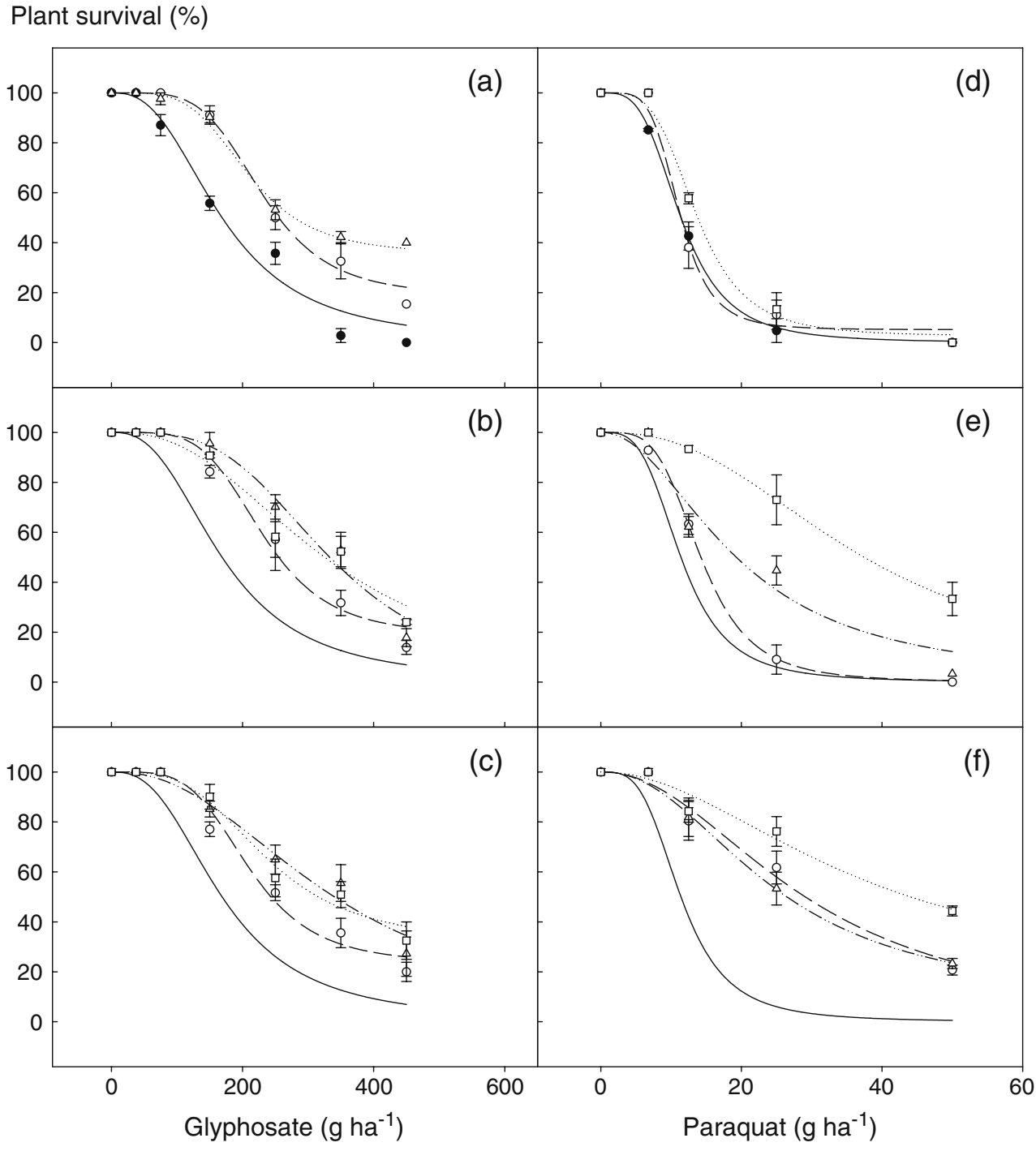


observed shift was well beyond the expected baseline variation for herbicide sensitivity to paraquat in unselected populations of L. rigidum or other species (Yu et al. 2004; Preston et al. 2005; Yu et al. 2007). Selection experiments repeated in time and place by conducting one experiment under controlled growth room conductions and one in field conditions showed the same evolution of glyphosate resistance and concomitant reduced paraquat sensitivity (Tables 1 and 2). Thus, genetic variability for reduced sensitivity to any particular herbicide can be rapidly selected within small populations of cross-pollinated species to result in population shifts towards higher levels of resistance (Neve and Powles 2005; Norsworthy et al. 2008). The same phenomenon can equally occur under controlled and commercial field conditions. For example, a L. rigidum population repeatedly selected at below-label herbicide rates under normal Australian farming conditions rapidly evolved resistance to different herbicide modes of action (Manalil et al. 2010). Similarly, in another species [Echinochloa phyllopogon (Stapf) Kossenko], a moderate level of cross-resistance to paraquat was indirectly selected by secondary photooxidative stresses caused by clomazone field applications (Yasuor et al. 2008).

\subsection{Potential mechanistic basis of reduced sensitivity to glyphosate and paraquat}

Glyphosate and paraquat are very different herbicides in their structural and chemical properties, mode of action (herbicide targets), and movement within plants. Glypyhosate resistance due to a single gene-endowed mechanism evident as reduced glyphosate translocation is well documented (reviewed by Powles and Preston 2006; Preston and Wakelin 2008; Shaner 2009; Powles and Yu 2010). Paraquat resistance due to a single gene-endowed mechanism evident as reduced paraquat translocation resistance is also well known (reviewed by Preston 1994). It is emphasized that these paraquat and glyphosate reduced translocation resistance mechanisms are completely independent and do not endow cross-resistance. Both of these genes can be present in the same individuals (Yu et al. 2007).

In this study, L. rigidum was selected only with glyphosate, and this led to concomitant reduced sensitivity to paraquat. Therefore, there must be a common mechanistic basis. One possibility is a tonoplast transporter(s) able to recognize both glyphosate and paraquat and sequester them in the vacuole (Ge et al. 2010; Yu et al. 2010). ABC transporters can be responsible for sequestration of toxic products such as herbicide metabolites and secondary products (Yuan et al. 2007; Ge et al. 2010). Thus, a gene super-family such as ABC transporters could be involved. However, other possibilities exist and need to be examined.

\section{Conclusions}

This is the first report that the selection of glyphosate resistance can be associated with concomitant reduced sensitivity to the completely different herbicide paraquat. The mechanistic basis of the observed reduced sensitivity to both glyphosate and paraquat remains to be determined and warrants future research, as these two globally-used herbicides are vital to world food production.

Acknowledgments The authors are grateful to Drs. Danica Goggin and Todd Gaines for critically reading earlier versions of the manuscript. The Australian Herbicide Research Initiative (AHRI) is funded by the Grains Research and Development Corporation of Australia (GRDC).

\section{References}

Busi R, Powles SB (2009) Evolution of glyphosate resistance in a Lolium rigidum population by glyphosate selection at sub-lethal doses. Heredity 103:318-325

Ge X, d'Avignon DA, Ackerman JJH, Sammons RD (2010) Rapid vacuolar sequestration: the horseweed glyphosate resistance mechanism. Pest Manage Sci 66:345-348

Heap IM (2010) International survey of herbicide resistant weeds. Available on URL: http://www.weedscience.org. Accessed December, 2010

Knezevic I, Streibig JC, Ritz C (2007) Utilizing R software package for dose-response studies: the concept and data analysis. Weed Technol 21:840-848

Lorraine-Colwill DF, Powles SB, Hawkes TR, Preston C (2001) Inheritance of evolved glyphosate resistance in Lolium rigidum (Gaud.). Theor Appl Genet 102:545-550

Manalil S, Busi R, Renton M, Powles SB (2010) Rapid evolution of herbicide resistance by low herbicide dosages. Weed Sci, in press

Neve P, Powles SB (2005) Recurrent selection with reduced herbicide rates results in the rapid evolution of herbicide resistance in Lolium rigidum. Theor Appl Genet 110:1154-1166

Norsworthy JK, Scott RC, Smith KL, Oliver LR (2008) Response of northeastern Arkansas Palmer Amaranth (Amaranthus palmeri) accessions to glyphosate. Weed Technol 22:408-413

Oerke EC (2006) Crop losses to pests. J Agric Sci 144:31-43

Owen MDK (2008) Weed species shifts in glyphosate resistant crops. Pest Manage Sci 64:377-387

Palumbi SR (2001) Evolution-humans as the world's greatest evolutionary force. Science 293:1786-1790

Powles SB (2008) Evolved glyphosate resistant weeds around the world: lessons to be learnt. Pesticide Manage Sci 64:360-365

Powles SB, Preston C (2006) Evolved glyphosate resistance in plants: biochemical and genetic basis of resistance. Weed Technol 20:282-289

Powles SB, Yu Q (2010) Evolution in action: plants resistant to herbicides. Annu Rev Plant Biol 61:317-347

Preston C (1994) Resistance to photosystem I disrupting herbicides. Herbicide resistance in plants. Biology and Biochemistry, pp 61-82

Preston C, Wakelin AM (2008) Resistance to glyphosate from altered herbicide translocation patterns. Pest Manage Sci 64:372-376

Preston C, Soar CJ, Hidayat I, Greenfield KM, Powles SB (2005) Differential translocation of paraquat in paraquat-resistant populations of Hordeum leporinum. Weed Res 45:289-295

Purba E, Preston C, Powles SB (1993) Inheritance of bipyridyl herbicide resistance in Arctotheca calendula and Hordeum leporinum. Theor Appl Genet 87:598-602 
Purba E, Preston C, Powles SB (1995) The mechanism of resistance to paraquat is strongly temperature dependent in resistant Hordeum leporinum link and H. glaucum Steud. Planta 196:464-468

Shaaltiel Y, Gressel J (1986) Multienzyme oxygen radical detoxifying system correlated with paraquat resistance in Conyza bonariensis. Pesticide Biochem Physiol 26:22-28

Shaner DL (2009) Role of translocation as a mechanism of resistance to glyphosate. Weed Sci 57:118-123

Yasuor H, TenBrook PL, Tjeerdema RS, Fischer AJ (2008) Responses to clomazone and 5-ketoclomazone by Echinochloa phyllopogon resistant to multiple herbicides in Californian rice fields. Pest Manage Sci 64:1031-1039

Yu Q, Cairns A, Powles SB (2004) Paraquat resistance in a population of Lolium rigidum. Funct Plant Biol 31:247-254
Yu Q, Cairns A, Powles S (2007) Glyphosate, paraquat and ACCase multiple herbicide resistance evolved in a Lolium rigidum biotype. Planta 225:499-513

Yu Q, Han H, Nguyen L, Forster JW, Powles SB (2009) Paraquat resistance in a Lolium rigidum population is governed by one major nuclear gene. Theor Appl Genet 118:1601-1608

Yu Q, Huang S, Powles SB (2010) Direct measurement of paraquat in leaf protoplasts indicates vacuolar paraquat sequestration as a resistance mechanism in Lolium rigidum. Pesticide Biochem Physiol 98:104-109

Yuan JS, Tranel PJ, Stewart CN (2007) Non-target-site herbicide resistance: a family business. Trends Plant Sci 12:6-13

Zelaya IA, Owen MDK, VanGessel MJ (2004) Inheritance of evolved glyphosate resistance in Conyza canadensis (L.) Cronq. Theor Appl Genet 110:58-70 